\title{
Çalışma sermayesinin firma kârlılığı üzerindeki etkisi: BİST KOBİ sanayi işletmelerinde bir araştırma
}

\section{The effect of working capital on firm profitability: A study in BIST SME industrial enterprises}

${ }^{1}$ Prof. Dr., K.S.Ü., İ̈BF, Kahramanmaras, Türkiye yucelayricay@ksu.edu.tr

ORCID: 0000- 0001-5148-391X

${ }^{2}$ Dr. Öğr. Üyesi, K.S.Ü., İ̈BF, Uluslararas1 Ticaret ve Lojistik Bölümü, Kahramanmaraş, Türkiye, meltemkilic@ksu.edu.tr

ORCID: 0000-0001-8978-9076

${ }^{3}$ K.S.Ü. S.B.E., İşletme Anabilim Dalı, Yüksek Lisans Öğrencisi, Kahramanmaraş, Türkiye sitaree@windowslive.com

ORCID: 0000-0002-9209-6454

\section{Sorumlu Yazar/Corresponding Author:}

Yasemin Güner, K.S.Ü. S.B.E., İșletme Anabilim Dalı, Yüksek Lisans Öğrencisi, Kahramanmaraş, Türkiye sitaree@windowslive.com

Başvuru/Submitted: 6/06/2021

$1^{\text {th }}$ Revizyon/Revised: $14 / 08 / 2021$

$2^{\text {nd }}$ Revizyon/Revised: 11/09/2021

Kabul/Accepted: 21/10/2021

Yayın/Online Published: 25/12/2021

Atıf/Citation: Ayrıçay, Y., \& Kılıç, M., \& Güner, Y., Çalışma sermayesinin firma kârlılığı üzerindeki etkisi: BİST KOBİ sanayi işletmelerinde bir araştırma, bmij (2021) 9 (4): 1238-1254, doi:

https://doi.org/10.15295/bmij.v9i4.1861

\author{
Yücel Ayrıçay ${ }^{1}$ \\ Meltem Kılıç2 \\ Yasemin Güner ${ }^{3}$
}

Öz

Çalışmanın amacı, çalışma sermayesi yatırım ve finansman değişkenlerinin firma kârlılığı üzerindeki etkisini incelemektir. Bu amaçla 2013 ve 2019 yılları arasında Borsa İstanbul'da (BİST) kayıtlı KOBI Sanayi Sektöründe (XKOBI) faaliyet gösteren 28 firmanın mali tabloları incelenmiştir. Firmaların çalışma sermayesi değişkenlerinin firma kârlılığı üzerindeki etkisini incelemek için panel veri regresyon analizinden yararlanılmıştır. Regresyon analizinde bağımlı değișkenler olarak öz sermaye kârlılığı (ROE) ve aktif sermaye kârlılı̆̆ı (ROA) kullanılırken, bağımsız değişkenlerde çalışma sermayesi yatırım politikaları, çalışma sermayesi finansman politikası, kontrol değişkeni olarak ise kaldıraç oranı ve satışların büyüklüğü kullanılmıştır. Ampirik analiz sonucunda, BİST'e kayıtlı KOBI'lerin çalışma sermayesi yatırım ve finansman politikalarının $\mathrm{ROA}^{\prime} \mathrm{y}$ ı pozitif yönde etkilediği sonucuna ulaşılmıştır. Diğer bağımlı değişken olan ROE ile yapılan testler sonucunda çalışma sermayesi yatırım politikasının özsermaye kârlılığını pozitif etkilemektedir. Diğer bir bağımsız değişken olan çalışma sermayesi finansman politikasının özsermaye kârlılığı üzerinde anlamlı bir etkisinin olmadığı tespit edilmiştir.

Anahtar Kelimeler: Çalışma Sermayesi Yönetimi, Firma Kârlılı̆̆ı, Panel Veri Analizi

Jel Kodları: M52, M31, E24

\begin{abstract}
The study examines the impact of working capital investment and financing variables on firm profitability. For this purpose, the financial statements of 28 companies operating in the SME Industry Sector (XKOBI) registered in Borsa Istanbul (BIST) between 2013 and 2019 were examined. In addition, panel data regression analysis was used to investigate the effect of working capital values of firms on firm profitability. The regression analysis used return on equity (ROE) and return on active capital (ROA) as dependent variables. Working capital investment policies and financing policies were used as independent variables. The leverage ratio and sales size were used as control variables. As a result of the empirical analysis, it has been concluded that the working capital investment and financing policies of SMEs registered in BIST positively affect ROA. Furthermore, the active capital investment policy positively affects the return on equity due to the tests performed with the other independent variable, ROE. On the other hand, working capital financing policy does not significantly affect the return on equity.
\end{abstract}

Keywords: Working Capital Management, Firm Profitability, Panel Data

Jel Codes: M52, M31, E24 


\section{Extended Abstract}

\section{The effect of working capital on firm profitability: A study in BIST SME industrial enterprises}

\section{Literature}

\section{Research subject}

The use of products and convertible and cash quickly is called working capital. Working capital is also referred to as working capital and working capital in different terms in the literature. (Çakır \& Küçükkaplan, 2012: 70). Firms make several financial decisions to maintain their assets healthily and increase their value in the market. However, they can keep their profitability and compete with these decisions. For companies to start their activities, continue their activities without interruption, and reach their goals, investment and financing decisions regarding how much their assets will be combined, their distribution, from which sources and how they will be financed are essential. Once the decision is made, it is difficult to change or fix. While there is a large amount of long-term resource transfer to fixed assets, investments in current assets keep company managers busy. Even if a firm has optimum fixed assets, mistakes in current asset investments cause liquidity, risk and profitability problems. Therefore, firms that want to increase their competitiveness should calculate and analyze their working capital correctly (Erdaş, 2015: 1220).

İn this context, companies should consider the firm's cash cycle, profitability and liquidity risk while planning their working capital investments and financing. Therefore, working capital is significant for the continuity and profitability of the companies.

\section{Research purpose and importance}

This study examines the effects of working capital investment and financing variables of BIST SME İndustrial enterprises on firm profitability. Although SMEs have an essential place in the country's economy, they are also suitable for development and transformation. Here, it is imperative to make appropriate investments and finance them using resources and assets to continue their activities without interruption.

\section{Contribution of the article to the literature}

The study is different, and the transition channel to the literature with other examples.

\section{Design and method}

\section{Research type}

In this study, the panel data analysis method was used, one of the quantitative research methods.

\section{Research problems}

Does working capital affect firm profitability in BIST SME industrial enterprises?

\section{Data collection method}

The study used data obtained from the financial statements of 28 companies operating in BIST SME Industrial Enterprises between 2013 and 2019.

These companies have been operating continuously in BIST between 2013-2019. For the data set of the study, the data obtained from the financial statements published on the website of the Public Disclosure Platform (KAP) were used.

\section{Quantitative/qualitative analysis}

In the study, firstly, complementary statistics of the variables used in the model were determined. Then, the variance amplification factor (VIF) was used to test whether there was a multicollinearity problem. Next, Levin-Lin-Chu (LLC) panel unit root analysis was performed to test the stationarity of the variables in the models used in the study. Then, to test whether the random effects model or the pooled most miniature squares model is appropriate in the established models, the Breush and Pagan Lm tests were conducted. As a result of this test, the F test was performed. According to these test results, the Hausman test is used to decide another estimator. As a result of this test, some assumption tests are made to determine whether heteroscedasticity, varying variance, autocorrelation, and correlation between units, exists in the random-effects model. Finally, due to all these tests, DriscollKraay Resistive Estimator Test and Beck-Katz Resistive Estimator tests were performed for two variables in the model.

\section{Research model}

\section{Model ROA:}

$R O A_{i t}=\alpha_{i t}+\beta_{1} C S Y P_{i t}+\beta_{2} C S F P_{i t}+\beta_{3} S B_{i t}+\beta_{4} L E V_{i t}+\varepsilon_{i t}$

$\mathrm{i}=1, \ldots \mathrm{N} ; \mathrm{t}=1, \ldots \mathrm{T}$

Model ROE

$$
R O E_{i t}=\alpha_{i t}+\beta_{1} \operatorname{CSYP}_{i t}+\beta_{2} \operatorname{CSFP}_{i t}+\beta_{3} S_{i t}+\beta_{4} L E V_{i t}+\varepsilon_{i t} \quad \mathrm{i}=1, \ldots \mathrm{N} ; \mathrm{t}=1, \ldots \mathrm{T}
$$

\section{Research hypotheses}

$H_{01}$ : Working capital investment policy has no effect on return on assets.

$H_{02}$ Working capital financing policy has no effect on return on assets.

$H_{03}$ : Leverage ratio has no effect on return on assets.

$H_{04}$ : The size of the sales has no effect on the return on assets.

$H_{05}$ : Working capital investment policy has no effect on return on equity.

$H_{06}$ : Working capital financing policy has no effect on return on equity. 
$H_{07}$ : Leverage ratio has no effect on return on equity.

$H_{08}$ : The size of the sales has no effect on the return on equity.

\section{Findings and discussion}

\section{Findings as a result of}

As a result of the study's analyses, the effect of working capital investment policy and financing policy on the return on assets ratio was statistically significant and positive; The impact of return on assets on leverage ratio is statistically significant and negative. İt has been concluded that the size of the sales does not affect the return on assets. In return on the equity model, the effect of working capital investment policy and scope of sales on return on equity is positive and statistically significant. However, it was determined that working capital financing policy did not have a common statistically significant effect on return on equity. The impact of the leverage ratio on return on equity is negative and statistically significant. The size of sales has a positive impact on effect on return on equity

\section{Hypothesis test results}

The results of the hypothesis tests are shown below.

\begin{tabular}{|c|c|c|c|}
\hline Hypotheses & Tests Used & P Significance Value & Decision \\
\hline $\boldsymbol{H}_{\mathbf{0 1}}$ & $\begin{array}{c}\text { Driscoll- Kraay Resist } \\
\text { Estimator }\end{array}$ & $\begin{array}{r}\mathrm{P}<0,05 \\
(\mathrm{P}<0,008)\end{array}$ & REJECTION \\
\hline $\boldsymbol{H}_{\mathbf{0 2}}$ & $\begin{array}{r}\text { Driscoll- Kraay Resist } \\
\text { Estimator }\end{array}$ & $\begin{array}{r}\mathrm{P}<0,05 \\
(\mathrm{P}<0,030)\end{array}$ & REJECTION \\
\hline $\boldsymbol{H}_{\mathbf{0 3}}$ & $\begin{array}{r}\text { Driscoll- Kraay Resist } \\
\text { Estimator }\end{array}$ & $\begin{array}{r}\mathrm{P}<0,05 \\
(\mathrm{P}<0,001)\end{array}$ & REJECTION \\
\hline $\boldsymbol{H}_{\mathbf{0 4}}$ & $\begin{array}{c}\text { Driscoll- Kraay Resist } \\
\text { Estimator }\end{array}$ & $\begin{array}{r}\mathrm{P}>0,05 \\
(\mathrm{P}>0,588)\end{array}$ & ACCEPTANCE \\
\hline $\boldsymbol{H}_{\mathbf{0 5}}$ & Beck-Katz Resist Estimator & $\begin{array}{r}\mathrm{P}<0,05 \\
(\mathrm{P}<0,001)\end{array}$ & REJECTION \\
\hline $\boldsymbol{H}_{\mathbf{0 6}}$ & Beck-Katz Resist Estimator & $\begin{array}{r}\mathrm{P}>0,05 \\
(\mathrm{P}>0,102)\end{array}$ & ACCEPTANCE \\
\hline $\boldsymbol{H}_{\mathbf{0 7}}$ & Beck-Katz Resist Estimator & $\begin{array}{r}\mathrm{P}<0,05 \\
(\mathrm{P}<0,000)\end{array}$ & REJECTION \\
\hline $\boldsymbol{H}_{\mathbf{0 8}}$ & Beck-Katz Resist Estimator & $\begin{array}{r}\mathrm{P}<0,05 \\
(\mathrm{P}<0,007)\end{array}$ & REJECTION \\
\hline
\end{tabular}

\section{Discussing the findings with the literature}

Working capital investment policy affects the return on assets positively. These results are the same as the results of "Şahin (2011) , Kaya and Konuk, (2020), Erbul and Özdemir (2020)". The effect of working capital financing policy on return on assets is also positive and significant. The results of "Topaloğlu, (2009), Nazir \& Afza, (2009) Al-Shubiri (2011)" gave different results for working capital financing. The leverage ratios of companies registered in the BIST SME index negatively affect the return on assets ratio." Çankaya (2020), Keskin \& Gökalp (2016), Şamiloğlu \& Demirgüneş (2008), Kedirli \& Çankaya (2016)" support the negative relationship between ROA and leverage ratio as a result of their studies.

The negative and significant result in ROE and leverage ratio gives the same result in the study of Yildiz and Deniz (2020). However, the size of the sales positively affects the return on equity. The effect of the size of the deals on the return on equity has similar results in the study of Kendirli and Konak (2014). As a result of the findings, the studies examined in the literature also show that the relationship between working capital and firm profitability is significant, and studies such as (Deloof, 2003; Dursun \& Ayrçay 2012; Keskin \& Gökalp 2016; Korkmaz \& Yaman 2019) support the results of the investigation.

\section{Conclusion, recommendation and limitations}

\section{Results of the article}

As a result of the study's analyses, the effect of working capital investment policy and financing policy on the return on assets ratio was statistically significant and positive; The impact of return on assets on leverage ratio is statistically significant and negative. It has been concluded that the size of the sales does not affect the return on assets. In return on the equity model, the effect of working capital investment policy and scope of sales on return on equity is positive and statistically significant. However, it was determined that working capital financing policy did not have a common statistically significant effect on return on equity. The impact of the leverage ratio on return on equity is negative and statistically significant.

\section{Suggestions based on results}

The necessity for SME İndustry companies in the BIST to operate with low leverage ratios or make the necessary policy changes to achieve more net profit than their assets stands out. But, on the other hand, it is also important whether there is a lack of equity among the reasons leading to more debt.

As a result of the study's analyses, it is seen that BIST SME Industry companies have adopted an aggressive working capital investment policy. Firms that adopt an aggressive operational capital investment policy prefer to keep liquidity low by investing less in current assets. İn this way, they create their support by increasing the level of risk. İn such cases, companies should have a minimum-security stock for cash and stocks. As is known, higher profitability is targeted in this policy. According to the regression results, it is seen that there is a positive relationship between return on assets and equity and working capital investment policies. İn this case, aggressive working capital increases the profitability of the firm.

BIST SME İndustrial companies seem to have increased their asset profitability with low-interest costs. İn the study, the positive effect of financing of working capital, defined by short-term liabilities, on total return on assets, and the opposite result in leverage ratios, suggests whether there is a problem with the efficient use of long-term foreign resources. Undoubtedly, this situation can be further investigated. However, the result could not be interpreted due to the insignificant relationship between return on equity and working capital financing policies. 


\section{Giriş}

Firmalar, varlıklarını sağlıklı bir şekilde devam ettirmek ve piyasadaki değerlerini artırmak amacıyla bir takım finansal kararlar alırlar. Ancak bu kararlar doğrultusunda kârlılıklarını sürdürülebilir ve rekabet edebilirler. Firmaların, faaliyetlerine başlamak, faaliyetlerini aksamaksızın sürdürmek ve hedeflerine ulaşabilmek için varlıklarının bileşiminin ne kadar olacağına, dağılımına, hangi kaynaklardan, nasıl finanse edileceğine ilişkin yatırım ve finansman kararları önemlidir. Karar verildikten sonra değiştirilmesi, düzeltilmesi zordur. Duran varlıklara, büyük tutarlı, uzun vadeli kaynak transferi söz konusuyken, dönen varlıklara yapılacak yatırımlar firma yöneticilerini sürekli meşgul etmekte, optimum duran varlığa sahip olsalar bile dönen varlık yatırımlarında yapılacak hatalar likidite, risk ve kârlılık sorunlarına yol açmaktadır. Rekabet gücünü artırmak isteyen firmalar çalışma sermayesini doğru bir şekilde hesaplamalı ve analiz etmelidir (Erdaş, 2015:1220).

Çalışma sermayesi, brüt çalışma sermayesi ve net çalışma sermayesi olarak ikiye ayrılmakta ve İşletmelerin faaliyetlerine başlaması ve devam ettirebilmesi için kısa sürede nakde çevrilebilen varlıklara yönelik yapılan harcamaları ifade etmektedir. Bir yıl içinde nakde dönüşebilen para, menkul kıymetler, alacaklar, stoklar, akreditif ve peşin ödenen giderler brüt çalışma sermayesini; çalışma sermayesi ile kısa vadeli yükümlülükler arasındaki fark ise net işletme sermayesini oluşturmaktadır (Sevil ve Başar, 2014: 163-164). Çalışma sermayesinin yönetimi, hangi varlığa ne miktarda yatırım yapılacağı ve bu yatırımların hangi kaynaklar ile finanse edileceğini öngörmektedir (Kendirli ve Konak, 2014: 4). Bu bağlamda, çalışma sermayesi yönetiminin amaçları; dönen varlıkların etkinliğini artırarak firma değerini yükseltmek, dönen varlık finansmanında kullanılan sermayenin maliyetini en aza indirmek ve borçların vadesinde ödenmesinde dönen varlıklara yönelik fon akışlarının kontrolünün sağlanması şeklinde sıralanabilir (Aksoy ve Yalçıner, 2008: 9).

Çalışma sermayesi yönetimi süreci, firmaların günlük faaliyetlerinden, girdilerin çıktıya dönüşmesine, gerçekleşen satışların sonucunda ortaya çıkan alacakların tahsil edilmesine ilişkin karar ve faaliyetlerle şekillenir. Bu süreç, firmanın nakit döngüsü, kârlılık ve likidite riski üzerinde etkilidir. Dolayısıyla, etkin yönetilen çalışma sermayesi işletmenin kârlılığını arttırarak nakit sıkıntısı ve borçlanma ihtiyacı gibi risklerin de ortadan kalkmasına yardımcı olur (Sevil ve Başar, 2014: 163-164). Firmaların büyüklüğü, türü, iş ve üretim hacmi ile ihtiyaç duyduğu çalışma sermayesi arasında yakın ilişki vardır; bunlara bağlı olarak ihtiyaç duyulan çalışma sermayesi miktarı farklılaşmaktadır. Örneğin, iş hacmi artıkça çalışma sermayesi ihtiyacı da artmaktadır. Artan ihtiyacı karşılarken firmalar çalışma sermayesine gereğinden fazla yatırım yaptıklarında kaynakların âtıl tutulmasından dolayı firma kârlılığı azalabilmektedir. Likidite riski ile kârlılık karşıtlığı nedeniyle çalışma sermayesinin optimal düzeyinin doğru belirlenmesi gerekir. Özellikle ekonomik kriz dönemlerinde çalışma sermayesi yönetiminde yapılan yanlışlıklar firmaların iflasına neden olabilmektedir (Aktaş, Doğanay, Gökmen ve Somuncu, 2017:246). Küreselleşmenin beraberinde getirdiği ulusal ve uluslararası finansal krizler uzun vadeli kaynak ve likidite sorununu ortaya çıkarmıştır. Bu durum firmaların kısa vadeli kaynaklara yönelmesine ve çalışma sermayesinin önem kazanmasına yol açmıştır (Çakır ve Küçükkaplan, 2012: 70; Dursun ve Ayriçay, 2012: 200).

Firmalar çalışma sermayesi optimizasyonu ile piyasadaki varlıklarını ve kârlılıklarını devam ettirmektedirler (Topaloğlu, 2019:89). Borsa İstanbul'a (BIST) kayıtlı firmaların rekabet edebilmek ve kârlılıklarını artırmaları için çalışma sermayesi yönetimine önem vermelerinin gerektiği çok sayıda çalışma tarafından ortaya konmuştur (Yıldız ve Deniz, 2020; Çınar ve Kaymaz, 2020; Eskin ve Güvemli, 2020; Topaloğlu, 2019; Akyüz, 2019; Konak ve Güner, 2016; Irmak, 2016; Güdelci, 2016; Atmaca, 2016; Zengin ve Tanrı̈̈ven, 2016; Doğan ve Elitaş, 2014; Albayrak ve Akbulut, 2012; Öz ve Güngör, 2007).

Çalışma sermayesi politikaları, yatııı ve finansman politikaları bakımından değerlendirilmektedir. Firmalar, uygulayacakları yatırım ve finansman politikalarıla ortaya çıkan getiri ve risk düzeyleri arasındaki dengeyi sağlamaya çalışmaktadır (Coşkun ve Kök, 2011: 75). Diğer bir ifadeyle, firmalar çalışma sermayesi tutarını belirlerken kârlılık ve riski dengelemek durumundadırlar. Çalışma sermayesine olduğundan fazla yatırım yapılırsa likidite artmakta buna bağlı olarak risk azalmakta ve firmaların kârlılıkları düşmektedir. Likit varlıklara yapılan fazla yatırım ve bunların uzun vadeli yabancı kaynaklar ile finanse edilmesi kârlılığı olumsuz etkilemektedir. Çalışma sermayesi yatırım ve finansman politikalarına göre bu durum muhafazakâr (ihtiyatlı) çalışma sermayesi politikası olarak ifade edilmektedir. Çalışma sermayesine daha az yatırım yapılması kısa vadeli yabancı kaynak kullanımını ve firmaların kârlılığını artırmakta ancak likidite oranını azaltmaktadır. Bu şekilde gerçekleşen çalışma sermayesi yatırım ve finansman politikası ise atak (agresif) çalışma sermayesi politikası olarak ifade edilmektedir (Ercan ve Ban, 2008: 281; Nazir ve Afza, 2009: 27; Okka, 2018: 252). Nazir ve Afza (2009) Çalışma sermayesinin optimum düzeyde ve etkin olmasının firmanın kârılı̆̆ğın artırmak isteyen yöneticilerin odağında olduğunu ifade etmektedir. 
Çalışmada, çalışma sermayesi yatırım ve finansman politikasının firma kârlılığı üzerindeki etkisi incelenmiştir. Bu kapsamda BİST'e kayıtlı Küçük ve Orta Ölçekli (KOBI)'ler analiz edilmiştir. "Yapılan OECD araştırmalarına göre Kobilerin finansman ihtiyacını gidermek için krediye başvurdukları ve yaşanacak olumsuzluklara karşı varlıklarını ve kaynaklarını kullanmakta büyük işletmelere göre daha yetersiz oldukları görülmektedir." (Arslan, 2003:122). Bu sebeple çalışma sermayesi yönetiminin iyi analiz edilerek işletmelerin finansal durumuna göre bir yol belirlemeleri olumsuzluklardan daha az etkilenmelerini ve firma kârlılığını arttıracağı öngörülmektedir. Çalışma iki bölümden oluşmaktadır. İlk bölümde çalışma sermayesi yönetimi, firma kârlılı̆̆ı, firma değeri ve firma performansı ile ilgili yapılan çalışmaları içeren literatür taramasına yer verilmiştir. İkinci bölümde ise, BİST'de işlem gören KOBİ sanayi işletmelerine ait 28 firmanın 2013-2019 yıllarını kapsayan verileri Panel Veri Analizi ile değerlendirilmiştir.

\section{Literatür taramas1}

Çalışma sermayesi yönetimi yatırım ve finansman politikalarının, devir hızlarının firma kârlılık oranları üzerindeki etkisi yabancı ve yerli literatürde incelenmiştir. Bu konu ile ilgili yapılan bazı çalışmalar şu şekildedir.

Deloof (2003), 1992-1996 yılları arasında Belçikalı 1009 büyük finansal olmayan firmalar araştırmıştır. Çalışmasında çalışma sermayesi yönetimi ile kurumsal kârlılık arasındaki ilişki incelemiştir. Çalışmanın sonuçları ise, yöneticilerin alacak hesaplarının ve envanterlerin gün sayısını azaltarak kurumsal kârlılığı artırabileceklerini göstermektedir.

Dursun ve Ayrıçay (2012), 1996-2005 kesintisiz olarak faaliyette bulunan BİST'e kayıtlı 120 firmanın verilerini kullanarak çalışma sermayesi ile brüt kâr arasındaki ilişkiyi araştırmışlardır. Çalışmalarının sonucunda, BİST'e kayıtlı firmalarda farklı değişkenlerle farklı düzeylerde ifade edilen çalışma sermayesinin, brüt kârlılık oranları ile ilişkilerinin teorik beklentiyle uyumlu olduğu sonucuna ulaşılmışlardır. Ayrıca, çalışma sermayesi değişkenleri ile brüt kârlılık arasında ters yönlü ilişki olduğunu tespit etmişlerdir.

Solano ve Teruel (2007), 1996-2002 yılları arasındaki Küçük ve Orta Ölçekli İspanyol firmaları üzerinde bir araştırma yapmışlardır. Yaptıkları çalışmada çalışma sermayesi yönetiminin, küucük ve orta ölçekli İspanyol firmalarından oluşan örneklemin kârlılık üzerindeki etkileri incelemişlerdir. Çalışmada bağımlı değişken olarak varlık getirisi (ROA) kullanılırken bağımsız değişken olarak alacak hesaplarının gün sayısı, stok gün sayısı ve ödenecek gün sayısı ele alınmıştır. İşletme sermayesi yönetimi panel veri analizi ile ölçmüşlerdir. Yapılan analizler sonucunda küçük ve orta ölçekli firmalarda değer yaratmada çalışma sermayesi yönetiminin önemli rolünü doğrulamaktadırlar. Kârlılık ile alacak hesaplarının gün sayısı ve envanter günleri arasında negatif bir ilişki olduğunu ifade etmişlerdir. Bununla birlikte, olası içsellik sorunlarının önemini yitirdiği ve ödenecek hesapların sayısının firmanın varlıklarının getirisini etkilemediği sonucuna ulaşmışlardır. Firmaların çalışma sermayesi yönetimi ile ilgilenmeleri gerektiğini ve nakit dönüşüm döngülerini minimuma indirerek değer yaratabileceklerini vurgulamışlardır.

Aytürk ve Yanık (2015), 2009-2013 yıllarında Türkiye' de faaliyet gösteren 1123 adet KOBİ'leri kapsayan çalışmasında işletme sermayesi yönetimi ile kârlılık arasındaki bağlantıyı araştırmışlardır. Panel veri analizi kullanarak yaptıkları çalışmada değişken olarak nakit döngüsü, brüt satış kârı/toplam varlıklar, vfök/toplam varlıklar, işletme büyüklügüu, satışların büyüme oranı, finansal kaldıraç oranı kullanmışlardır. Bu analizler sonucunda ise nakit döngüsü ile kârlılık arasında negatif bir ilişki olduğu görülmektedir. Türkiye' deki KOBI'lerde işletme sermayesinin aktif yönetimin kârlılık üzerinde arttırıcı etkisi tespit etmişlerdir.

Pais ve Gama (2015), 2002 ve 2009 dönemini kapsayan çalışmasında 6063 küçük ve orta ölçekli Portekiz firmasını incelemişlerdir. Çalışmalarında Portekiz firmalarının çalışma sermayesi yönetiminin kârlılık üzerindeki etkisini analiz etmişlerdir. Ampirik analizler sonucunda, tutulan stoklarda ve firmaların ticari yükümlülüklerini yerine getirmek ve müşterilerinden ödeme almak için harcadıkları gün sayısında bir azalmanın daha yüksek kurumsal kârlılıkla ilişkili olduğunu belirlemişlerdir. Kârlılığın ikinci dereceden bağımlılıklarının bazı değişkenler üzerinde ilgili olduğu görülmektedir. İşletme sermayesi yönetiminin değişkenlerinin artan değerleri ile varlıklar üzerindeki getiri eğiliminin azaldığını ifade etmişlerdir.

Poyraz (2012), 1988 ve 2011 yılları arasındaki Akbank'ın mali tablolarını incelemiştir. Çalışmasında çalışma sermayesi finansal politikalarının kârlılığa olan etkisini incelemeyi amaçlamaktadır. Yöntem olarak korelasyon ve çoklu regresyon analizi kullanmıştır. Bağımlı değişken; özsermaye kârlılık oranı ve aktif kârlılık oranı iken bağımsız değişken; cari oran, uzun vadeli yabancı kaynak oranı, kısa vadeli 
yabancı kaynak oranı, devamlı sermaye oranını hesaplamıştır. Cari orandaki değişiklilerin kârlılık oranlarına olan etkisi negatif yönlü ve önemli bir etki olduğunu bulgulamıştır.

Sharif ve Islam (2018), Bangladeş'teki ilaç endüstrisinin çalışma sermayesi ile kârlılık işlevi arasındaki ilişkisini incelemişlerdir. Çalışmada bağımsız değişken gün cinsinden hesap alınarak devir hızı, ödenecek hesap devir hızı, stok devir hızı ve nakit dönüştürme döngüsü kullanılırken; bağımsız değişkenler, aktif kârlılık oranı, kontrol değişkeniler ise firma büyüklüğü, kaldıraç oranı, cari oran ve satışlar kullanmışlardır. Çalışmanın analizinde çoklu regresyon ve korelasyon testi yapmışlardır. Ampirik analizler sonucunda bağımlı değişken ve incelenen değişkenler arasında anlamlı bir ilişki olduğu bulgulamışlar; ayrıca, çalışma sermayesinin firmanın kârlılı̆̆ı üzerinde önemli bir etkisi olduğundan bahsedilen sıfır hipotezlerinin reddedildiğini tespit etmişlerdir. Bangladeş'teki ilan firmalarının rekabetçi bir ortamda ayakta kalabilmek için çalışma sermayesi yönetimi uygulamaları yeniden düzenlemeleri gerektiği açıklamışlardır. Aynı şekilde Le (2018) 2007 ve 2016 dönemini kapsayan Ho Chi Minh ve Hanoi Borsasında listelenen Vietnamlı 497 firmayı incelemiştir. Firmaların çalışma sermayesi yönetimlerine önem vermesi gerektiğini ifade etmiştir.

Altaf ve Ahmad (2019), 2007 ve 2016 yıllarını kapsayan çalışmada 437 finansal olmayan Hintli firmanın çalışma sermayesi finansmanı ile firma performansı arasındaki ilişkiyi incelemiştir. Çalışmanın amacı, finansal kısıtlamaların çalışma sermayesi finansmanı ve performans ilişkisi üzerindeki etkisini incelemektir. Bağımsız değişkenlerde çalışma sermayesi finansmanı (WFC) kullanılmakta, bağımlı değişkende ise aktif kârlılık oranı (ROA) ve kontrol değişkeni olarak da firma büyüklügüu, büyüme, varlık somutluğu, firma yaşı ve kaldıraç oranı kullanılmaktadır. Bu değişkenlerin değerlendirilmesi sonucunda çalışma sermayesi finansmanı ile firma performansı arasındaki ters $U$ şeklinde ilişki bulunmuştur. Bununla birlikte finansal olarak daha az kısıtlama olasılığ yüksek olan firmaların, kısa vadeli borç kullanarak çalışma sermayesinin daha büyük bir kısmını finanse edebileceklerini tespit etmişlerdir.

Prasad, Sivasankaran ve Shukla (2019), Bombay Menkul Kiymetler Borsası'na ait 500 firmanın 20122017 yılları arasındaki verilerini kullanarak çalışma sermayesinin hedef yatııımdan sapmanın kârlılık ve net işletme geliri üzerindeki etkisini değerlendirmektedirler. Çalışmanın sonucunda Hintli firmaların net ticaret döngüsü oluşturduğu ve herhangi bir sapma durumunda yakınlaşmaya çalıştığını ortaya koymuşlardır. Ayrıca, çalışma sermayesindeki sapmanın hedef yatırım seviyesinin üzerinde veya altında olmasına bakılmaksızın, örnek firmaların kârlılı̆̆ının hedef net ticaret döngüsünden sapmadan etkilendiği görülmüştür.

2018-2020 yıllarında çalışma sermayesinin BİST'deki farklı endekslerde faaliyet gösteren firmaların çalışma sermayesi değişkenlerinin firma kârlılığı ve değeri üzerindeki etkisi regresyon analizleri ile incelenmiştir (Öndeş ve Pagheh 2018, Topaloğlu 2019; Akyüz ve Atmaca 2019; Erbul ve Özdemir 2020). Çalışmalarda bağımsız değişken olarak çalışma sermaye değişkeni olarak alacak devir hızı, stok devir hızı, cari oran, çalışma sermayesi yatırım ve finansman politikası değerleri gibi değişkenler; bağımsız değişken olarak firma kârlılık oranları ve firma değeri oranları kullanılmıştır. Yaptıkları analizler sonucunda çalışma sermayesi değişkenlerinin firma kârlılığı ve değerini farklı yönlerden etkilediği sonucu bulunmuştur.

\section{Araştırmanın amacı, veri seti ve modeli}

Çalışmanın amacı, firmaların çalışma sermayesi yönetimindeki değişkenlerin firma kârlılığı üzerindeki etkisini incelemektedir. Çalışmada, 2013 ve 2019 yılları arasında BİST KOBİ Sanayi İşletmelerinde faaliyet gösteren 28 firmanın mali tablolarından elde edilen veriler kullanılmıştır.

Söz konusu firmalar 2013-2019 yılları arasında BİST'de sürekli faaliyet gösteren firmalardır. Çalışmanın veri seti için Kamu Aydınlatma Platformu'nun (KAP) internet sitesinde yayımlanan mali tablolardan elde edilen veriler kullanılmıştır. Çalışma veriler Kamu Aydınlatma Platformu'nun internet sitesinden elde edildiği için etik kurul izni gerektirmemektedir.

\section{Modelde kullanılacak değişkenler}

BİST'e kayıtlı Kobilerde çalışma sermayesi yönetiminin firma kârlılığı üzerindeki etkisini ölçmek için üç farklı değişken kullanılmıştır.

Bağımlı değişkenler: Çalışmada işletmenin kârlılığını belirlemek için aktif kârlılık ve özsermaye kârlılığı olmak üzere iki adet oran kullanılmıştır. 
Aktif kârlılık, net kârın toplam aktiflere bölünmesi ile bulunur. Aktif kârlılığın kullanıldığı daha önceki çalışmalardan bazıları da şöyledir; "Yücel ve Kurt (2002), Şamiloğlu ve Demirgüneş (2008), Aygün (2012), Garcia-Teruel ve Martinez-Solo (2007), Sharif ve İslam, (2018)".

Özsermaye kârlılı̆̆ı, net kârın özsermayeye bölünmesi ile bulunur. Özsermaye kârlılık oranı belirlenirken konuyla alakalı yapılan çalışmalardan "Aydoğmuş, (2014), Poyraz (2012), Çerçel ve Sökmen (2019), Akyüz, (2019)" gibi kaynaklardan yararlanılmıştır.

Bağımsız değişkenler: Çalışma sermayesinin yönetiminin ölçülmesin inceleyen "Altaf ve Ahmad, (2019), Topaloğlu (2019), Erbul ve Özdemir (2020)" gibi çalışmaların incelenmesi sonucunda çalışma sermayesi yatırım politikaları ve çalışma sermayesi finansman politikaları bağımsız değişken olarak belirlenmiştir.

Kontrol değişkenleri: Kontrol değişkenleri kurulmak istenen modellerde yapılan analizlerin sonucunda bağımlı ve bağımsız değişkenler arasındaki açıklayıcılığı ve güvenliği artırmak için kullanılmaktadır. Bu sebeple incelenen "Kendirli ve Konak (2014), Aytürk ve Yanık, (2015), Kısakürek, Babacan ve Tuncay, (2018), Akyüz ve Atmaca, (2019)" gibi çalışmaların incelenmesi sonucunda satışların büyüklüğü ve kaldıraç oranları kontrol değişkeni olarak belirlenmiştir.

BIST KOBİ endeksindeki firmaların çalışma sermayelerinin firma kârlılıkları üzerindeki etkisini araştırmak için Tablo 1'deki bağımlı ve bağımsız değişkenler kullanılmıştır.

Tablo 1: Çalışmada Kullanılan Değişkenler

\begin{tabular}{|c|c|c|}
\hline \multicolumn{3}{|c|}{ Bağımlı Değişkenler } \\
\hline Gösterimi & Değişkenin Adı & Hesaplanma Yöntemi \\
\hline ROA & Aktif Kârlılık Oranı & Net Kâr/Toplam Aktif \\
\hline ROE & Özsermaye Kârlıı̆̆ı & Net Kâr/ Özsermaye \\
\hline \multicolumn{3}{|c|}{ Bağımsız Değişkenler } \\
\hline Gösterimi & Değişkenin Adı & Hesaplanma Yöntemi \\
\hline CSYP & Çalı̧̧ma Sermayesi Yatırım Politikaları & Toplam Dönen Varlık/ Toplam Varlık \\
\hline CSFP & Çalışma Sermayesi Finansman Politikası & $\begin{array}{c}\text { Kısa Vadeli Yükümlülükler /Toplam } \\
\text { Varlık }\end{array}$ \\
\hline \multicolumn{2}{|c|}{ Kontrol Değişkenleri } \\
\hline LEV & Kaldıraç Oranı & (Kvykk + Uvyk) / Toplam Aktifler \\
\hline SB & Satı̧ların Büyüklüğü & $\begin{array}{c}\text { (Satışlar- Bir Önceki Yıl Satışları) / Bir } \\
\text { Önceki Yıl Satışlar }\end{array}$ \\
\hline
\end{tabular}

Çalışmada kullanılan bağımlı ve bağımsız değişkenler ile kurulan ve sınanacak olan sıfır hipotezleri aşağıdaki gibidir.

$\boldsymbol{H}_{\mathbf{0 1}}$ : Çalışma sermayesi yatırım politikasının aktif kârlılık üzerinde etkisi yoktur.

$\boldsymbol{H}_{\mathbf{0 2}}$ : Çalışma sermayesi finansman politikasının aktif kârlılık üzerinde etkisi yoktur.

$\boldsymbol{H}_{\mathbf{0 3}}$ : Kaldıraç oranının aktif kârlılık üzerinde etkisi yoktur.

$\boldsymbol{H}_{\mathbf{0 4}}$ : Satışların büyüklüğ̈̈̈nün aktif kârlllı üzerinde etkisi yoktur.

$\boldsymbol{H}_{\mathbf{0 5}}$ : Çalışma sermayesi yatırım politikasının özsermaye kârlılık üzerinde etkisi yoktur.

$\boldsymbol{H}_{\mathbf{0 6}}$ : Çalışma sermayesi finansman politikasının özsermaye kârlllık üzerinde etkisi yoktur.

$\boldsymbol{H}_{\mathbf{0 7}}$ : Kaldıraç oranının özsermaye kârlllık üzerinde etkisi yoktur.

$\boldsymbol{H}_{\mathbf{0 8}}$ : Satışların büyüklü̈̆̈̈nnün özsermaye kârlllı üzerinde etkisi yoktur.

Kurulan hipotezler dikkate alınarak bağımlı ve bağımsız değişkenler ile iki regresyon modeli kurulmuştur. Bu modeller aşağıdaki gibidir:

Model ROA:

$R O A_{i t}=\alpha_{i t}+\beta_{1} C S Y P_{i t}+\beta_{2} \operatorname{CSF} P_{i t}+\beta_{3} S B_{i t}+\beta_{4} L E V_{i t}+\varepsilon_{i t} \quad \mathrm{i}=1, \ldots \mathrm{N} ; \mathrm{t}=1, \ldots \mathrm{T}$ 
Model ROE

$$
R O E_{i t}=\alpha_{i t}+\beta_{1} \operatorname{CSYP}_{i t}+\beta_{2} \operatorname{CSFP}_{i t}+\beta_{3} S B_{i t}+\beta_{4} L E V_{i t}+\varepsilon_{i t} \quad \mathrm{i}=1, \ldots \mathrm{N} ; \mathrm{t}=1, \ldots \mathrm{T}
$$

\section{Araştırma yöntemi ve bulguları}

Çalışmada zaman boyutu ve yatay kesit baz alınarak bağımsız değişkenlerin bağımlı değişken üzerindeki etkisini belirlemek içinde panel veri regresyon analizi yapılmıştır. 3 tür panel veri regresyon modeli vardır. Bu regresyon modellerinden hangisinin kurulan modeller için uygun olacağını tespit etmek için Breush-Pagan Lagrange çarpan (LM) testi, F testi ve Hausman testleri yapılmıştır (Kılıç, 2019: 51). Uygun regresyon modelini belirlemek için yapılacak testlerden önce modelde kullanılan değişkenlerin tanımlayıcı istatistikleri belirlenmiştir. Aşağıdaki tabloda tanımlayıcı istatistik özetleri yer almaktadir.

Tablo 2: Tanımlayıcı İstatistikler

\begin{tabular}{|c|c|c|c|c|c|c|}
\hline & ROA & ROE & CSYP & CSFP & SB & LEV \\
\hline Gözlem Sayısı & 196 & 196 & 196 & 196 & 196 & 196 \\
\hline Ortalama & 0.0223 & 0.0105 & 0.5249 & 0.3185 & 0.2426 & 0.4447 \\
\hline Standart Sapma & 0.1357 & 0.3147 & 0.2259 & 0.1976 & 0.6152 & 0.2388 \\
\hline $\begin{array}{c}\text { Maksimum } \\
\text { Değer }\end{array}$ & 0.9953 & 1.9405 & 0.9435 & 1.1682 & 4.4653 & 1.2289 \\
\hline Minimum Değer & -0.3424 & -1.4059 & 0.0587 & 0.0110 & -0.9993 & 0.02412 \\
\hline
\end{tabular}

Tanımlayıcı istatistik sonuçlarına göre en yüksek ortalamaya sahip değişken çalışma sermayesi yatırım politikası, en düşük ortalamaya sahip değişken ise özsermaye kârlılığıdır. En yüksek standart sapma satışların büyüklüğü değişkenindedir. En düşük standart sapma ise aktif kârlılık oranındadır. Bu bağlamda, satışlardaki oynaklığa rağmen aktif kârlılık oynaklığının az olması dikkat çekicidir. Modelin tanımlayıcı istatistikleri sonrasında çoklu doğrusal bağlantı analizi yapılmaktadır.

Regresyon modellerinde yer alan bağımsız değişkenler arasında doğrusal ilişkilerin olmaması yani sapmasız tahminler elde edebilmek için çoklu doğrusal bağlantı analizi yapılmaktadır. Çoklu doğrusal bağlantı sorununun olup olmadığını test etmek için varyans büyütme faktörü (VIF) ile hesaplanmaktadır. VIF, modeldeki bağımsız değişkenlerin tek tek bağımlı değişken, kalan bağımsız değişkenlerin ise bağımsız değişkenler olarak yer aldığı yardımcı regresyon modelinden elde edilen $R^{2}$ değerleri ile hesaplanmaktadır. VIF değerinin $5^{\prime}$ ten küçük olması çoklu doğrusal bağlantı probleminin olmadığını ifade etmektedir (Tatoğlu, 2020:260).

Çalışmada kurulan ROA ve ROE modellerinde çoklu doğrusal bağlantı VIF kriteri ile sınanmıştır. VIF kriterine göre elde edilen sonuçlar Tablo 3'te gösterilmektedir.

Tablo 3: (VIF) Varyans Büyütme Faktör Testi

\begin{tabular}{|l|l|l|l|l|}
\hline & \multicolumn{2}{|c|}{ ROA } & \multicolumn{2}{c|}{ ROE } \\
\hline & VIF & $1 /$ VIF & VIF & $1 /$ VIF \\
\hline CSFP & 6.48 & 0.1543 & 6.48 & 0.1543 \\
\hline CSYP & 6.30 & 0.1586 & 6.30 & 0.1586 \\
\hline LEV & 1.10 & 0.9108 & 1.10 & 0.9108 \\
\hline SB & 1.02 & 0.9108 & 1.02 & 0.9108 \\
\hline MEAN VIF & 3.73 & 3.73 \\
\hline
\end{tabular}

VIF sonuçlarına göre kurulan regresyon modellerinde ortalama VIF değeri 5 'in altında $(3.73<5)$ olduğundan dolayı çoklu doğrusal bağlantı problem olmadığı tespit edilmiştir.

Çalışmada kullanılan modellerdeki değişkenlerin durağanlığını test etmek için Levin-Lin-Chu (LLC) panel birim kök analizi yapılmıştır. LLC panel birim kök analizi için sınanan sıfır hipotezi aşağıdaki gibidir.

\section{$H_{0}$ : Birim Kök vardır}

LLC birim kök analizi sınaması Tablo 4'te özetlenmektedir. 
Tablo 4: LLC Birim Kök Analizi Sonuçları

\begin{tabular}{|l|l|l|}
\hline & \multicolumn{2}{|c|}{ Düzeyde ve Sabit } \\
\hline & Istatistik değeri & Olasılık Değeri \\
\hline ROA & $-37.3637^{*}$ & 0.0000 \\
\hline ROE & $-5.42551^{*}$ & 0.0000 \\
\hline CSYP & $-6.79018^{*}$ & 0.0000 \\
\hline CSFP & $-62.8349^{*}$ & 0.0000 \\
\hline LEV & $-49.486^{*}$ & 0.0000 \\
\hline SB & $-13.9831^{*}$ & 0.0000 \\
\hline
\end{tabular}

Bağımlı ve bağımsız değişkenlerin tek tek sınandığı LLC birim kök testi sonucunda sıfır hipotezi reddedilmektedir. Diğer bir ifadeyle, serilerde birim kök yoktur ve düzeyde durağandır.

Breusch-Pagan (1979) LM testi ile doğrusal regresyon modelinde heteroskedastik olduğu için geliştirmiştir (Breush ve Pagan, 1979: 1287). Bu test ile kurulan modelde rassal etki modelinin mi yoksa havuzlanmış en küçük kareler modelinin mi uygun olup olmadığı sınanmaktadır. Kurulan hipotez aşağıdaki şekildedir:

\section{$H_{0}:$ Rassal birim etkilerin varyansı sı firdır.}

Bu hipotez havuzlanmış EKK modelinin kurulan hipotez için seçilmesi gerektiğini ifade etmektedir.

Tablo 5: Breush ve Pagan LM Testi Sonuçları

\begin{tabular}{|c|c|c|}
\hline & Model ROA & Model ROE \\
\hline $\boldsymbol{x}^{2}$ istatistiği & $37.19^{*}$ & $26.21^{*}$ \\
\hline Olasılık değeri & 0.0000 & 0.0000 \\
\hline
\end{tabular}

Not: *(\%1) düzeyini belirtmektedir.

Breush-Pagan LM testi sonucunda $\mathrm{H}_{0}$ hipotezi $\% 1$ anlamlılık düzeyinde reddedilmektedir. Bu sonuç kurulan her iki modelde havuzlanmış en küçük kareler regresyon modelinin seçilmediği, rassal etki modelinin kullanılması gerektiğini göstermektedir.

Sabit etkiler regresyon modeli ile havuzlanmış en küçük kareler modeli arasında seçim yapmak için F testi kullanılmaktadır. F testi veriler ile birimler arasında farklılık olup olmadığını test etmek amacıyla yapılır. Test sonucunda kurulan regresyon modellerinde havuzlanmış en küçük kareler yöntemiyle mi yoksa sabit etki modeliyle analiz yapılacağı belirlenmektedir. F testti hipotezi ( Tataoğlu, 2012: 164);

$H_{0}$ :Veriler birimlere göre farklıllk göstermiyor.

şeklindedir. Bu hipotez sınamasına göre F testi sonuçları Tablo 6'da özetlenmiştir.

Tablo 6: F Testi Sonuçları

\begin{tabular}{|c|c|c|}
\hline & Model ROA & Model ROE \\
\hline F istatistiği & $3.99^{*}$ & $2.80^{*}$ \\
\hline Olasılık değeri & 0.0000 & 0.0000 \\
\hline
\end{tabular}

Not: *(\%1), ** (\%5), *** (\%10) düzeyini belirtmektedir.

$\mathrm{Bu}$ tablodaki sonuçlarına göre olasılık değerleri \%1'de anlamlı olduğundan dolayı $H_{0}$ hipotezi reddedilmektedir. Bu sonuç her iki regresyon modeli için rassal etki modeli analizinin kullanılması gerektiğini ifade etmektedir. F testti ve Breush-Pagan LM testleri havuzlanmış EKK modeli ile regresyon analizi yapılmaması gerektiğini ifade etmektedir. Bu sonuçlara göre bir diğer tahminciler arası karar verme testi olan Hausman testine bakılmaktadır.

Rassal etki modeli asimptotik olarak verimli bir tahmincidir, sabit etki modeli ise tarafsız ve tutarlı bir tahmincidir (Hausman, 1980:1263). Sabit etki ve rassal etki modellerinin en önemli farklılıklarından biri, 
birim etkinin bağımsız değişkenlerle arasında korelasyon olup olmadığıdır. Hausman testi ile korelasyonun olup olmadığı test edilmektedir. Bu kapsamda kurulan hipotez şu şekildedir (Tatoğlu, 2012:180)

\section{$H_{0}$ : Açılklayıcı değişkenler ve birim etki arasında korelasyon yoktur}

Sıfır hipotezinin kabul edilmesi modelde rassal etki modelinin olduğunu ifade etmektedir. Çalışmadaki modeller ile yapılan Hausman testi sonuçları Tablo 7' de özetlenmiştir.

Tablo 7: Hausman Test Sonuçları

\begin{tabular}{|c|c|c|}
\hline & Model ROA & Model ROE \\
\hline Hausman istatistiği & 9.04 & 1.43 \\
\hline Olasılık değeri & 0.0602 & 0.8382 \\
\hline
\end{tabular}

Tablo 7' deki test sonuçlarında modellerin ikisi de 0,05 ten büyük olduğu için anlamlı değildir. Hausman olasılığına göre 0,05 ten büyük olduğu için $H_{0}$ hipotezi reddedilemez. Dolayısıyla sabit etkiler modeli uygun değildir. Bu sonuçlara göre tesadüfi etkiler modeli daha uyundur.

Panel veri regresyon tahmincisine kadar vermek için yapılan Breush-Pagan LM, F testi ve Hausman testi sonuçlarından Model ROA ve Model ROE için en uygun testin rassal etki modelinin uygun olduğu sonucuna ulaşılmıştır. Rassal etki modelinde heteroskedasite yani değişen varyans, otokorelasyon ve birimler arası korelasyon var olup olmadığını belirtmek için bazı varsayım sınamaları yapılmaktadır.

Heteroskedasite varsayım testi ile kurulan modellerde değişen varyans problemi olup olmadığı test edilmektedir. Değişen varyans problemi için Levene, Brown ve Forsthe testi yapılmıştır.

Levene (1960) çalışmasında varyans eşitliği için test istatistiklerinin normal dağılmadığını ortaya koymuştur (Brown ve Forsythe, 1974: 364). Bunun sonucunda dirençli bir heteroskedasite testi önermiştir (Tatoğlu, 2012: 222). Brown ve Forsythe (1974) çalışmasında Levene'nin çalışmasına ek olarak ortalamanın yerine daha güçlü yerel bir tahminci önermişlerdir (Brown ve Forsythe, 1974: 364). Heteroskedasite testinin hipotezi aşağıdaki şekilde kurulmaktadır.

$H_{0}$ : Birimlerin Varyansları Eşittir.

Çalışmada Model ROA ve Model ROE için test edilen değişen varyans testi sonuçları Tablo 8'de özetlenmiştir.

Tablo 8: Değişen Varyans Testi

\begin{tabular}{|c|c|c|}
\hline & Model ROA & Model ROE \\
\hline \multirow{2}{*}{ W0 } & $2.9537^{*}$ & $4.0943^{*}$ \\
& $(0.0000)$ & $(0.0163)$ \\
\hline \multirow{2}{*}{ W50 } & $1.2632^{* * *}$ & $1.7655^{*}$ \\
& $(0.1875)$ & $(0.0163)$ \\
\hline \multirow{2}{*}{ W10 } & $2,954^{*}$ & $4.0942^{*}$ \\
& $(0.0000)$ & $(0.0000)$ \\
\hline
\end{tabular}

Değişen varyans testi sonuçları Snedecor F tablosu ile karşılaştırmış ve değişen varyans sonuçlarına göre sıfır hipotezi reddedilmiştir. Bu sonuç Model ROA ve Model ROE'de değişen varyans probleminin olduğunu göstermektedir.

Diğer varsayım testlerinden otokorelasyon testi Bhargava vd. Durbin Watson ve Baltagi Wu LBI testi ile birimler arası korelasyon ise Pesaran CD testleri ile analiz edilmiştir. Otokorelasyon testlerine göre modelde otokorelasyon olmaması için değerin 2'i olması gerekmektedir. Birimler arası korelasyonun sınanması için kurulan $\mathrm{H}_{0}$ hipotezi ise aşağıda belirtilmiştir.

$H_{0}$ : Birimler arası otokorelasyon yoktur.

Her iki varsayım testi sonuçları Tablo 9'da gösterilmektedir. 
Tablo 9: Otokorelasyon ve Birimler Arası Korelasyon Test Sonuçları

\begin{tabular}{|c|c|c|c|}
\hline & \multicolumn{2}{|c|}{ Otokorelasyon Testi } & $\begin{array}{c}\text { Birimler Aras1 Korelasyon } \\
\text { Testi }\end{array}$ \\
\hline & $\begin{array}{c}\text { Bhargava vd. Durbin- } \\
\text { Watson }\end{array}$ & Baltagi_Wu LBI & Pesaran CD Test \\
\hline Model ROA & 1.6840334 & 1.9081828 & $4.138^{*}$ \\
\hline Model ROE & 1.3641996 & 1.798594 & $(0.0000)$ \\
\hline
\end{tabular}

Not: *(\%1) düzeyini ifade belirtmektedir.

Tablo 9'da açıklanan otokorelasyon sonuçları 2'den küçüktür. Bu sebeple kurulan modelde otokorelasyon probleminin var olduğu sonucuna ulaşılmıştır. Pesaran CD birimler arasındaki korelasyonu tespit etmek için yapılır. Bu test sonuçlarına göre Model ROA'da birimler arası korelasyon sorunu olduğuna ulaşılmış ve sıfır hipotezi reddedilmiştir. Ancak Model ROE'de birimler arası korelasyon testi hipotezi kabul edilmiştir. Bu sonuç ROE modelinde birimler arası korelasyonun olmadığını göstermektedir.

Model ROA ve Model ROE için yapılan varsayım testleri sonucunda her iki regresyon modelinin dirençli tahminciler ile analiz edilmesine karar verilmiştir.

Model ROA için heteroskedasite, otokorelasyon ve birimler arası korelasyon sorunlarını ortadan kaldırarak modelin tahmin edilmesini sağlayan Driscoll-Kraay Dirençli Tahmincisi kullanılmıştır (Tataoğlu, 2020:339).

Driscoll ve Kraay (1998) genel parametrik olmayan kovaryans martis tahmin tekniklerinin basit bir uzantısının zamansal ve uzamsal boyutu bütün formlarında dirençli olabilecek şekilde geliştirilebileceğini ifade etmektedir. Driscoll ve Kraay tahmincisi, büyük zaman boyutu asimptotiklerine dayanan tahmincilerin eksiklerini gideren standart parametrik olmayan zaman serisi kovaryans matrisi tahmincisinin basit bir modifikasyonudur. (Driscoll ve Kraay, 1998:549-550). Model ROA ile tahmin edilen Driscoll ve Kraay dirençli tahmincisi sonucu Tablo 10' da açılanmıştır.

Tablo 10: Model ROA Driscoll- Kraay Dirençli Tahminci Test Sonucu

\begin{tabular}{|c|c|c|}
\hline & Katsay1 & P>|T \\
\hline CSYP & $0,2014^{*}$ & 0,008 \\
\hline CSFP & $0,1447^{* *}$ & 0,030 \\
\hline LEV & $-0,3041^{*}$ & 0,001 \\
\hline SB & $-0,0806$ & 0,588 \\
\hline SABIT & 0,0076 & 0,852 \\
\hline \multicolumn{2}{|c|}{ Wald chi2(4) } & $045.89^{*}$ \\
\hline \multicolumn{2}{|c|}{ Prob> chi2 } \\
\hline
\end{tabular}

Not: ${ }^{*}(\% 1)$ ve ${ }^{* *}(\% 5)$ anlamlllık düzeyini belirtmektedir.

Tablo 10'daki sonuca göre kurulan ROA modeli istatistiksel olarak \%1'de anlamlıdır. Modeldeki değişkenlerin aktif kârlılık oranı üzerindeki etkisi ise şu şekildedir. Çalışma sermayesi yatırım politikası aktif kârlılığı \%1 anlamlılık düzeyinde ve pozitif yönde etkilemektedir. Ayrıca, çalışma sermayesi yaptırım politikasındaki bir birimlik bir artış aktif kârlılık oranını \%20,14 etkilemektedir. Bu sonuçlar "Şahin (2011), Kaya ve Konuk, (2020), Erbul ve Özdemir (2021)" sonuçları ile aynıdır. Çalışma sermaye finansman politikasının aktif kârlılık üzerindeki etkisi de pozitif yönlü ve \%5'te anlamlıdır. Çalışma sermayesi finansman politikasındaki bir birimlik artış aktif kârlılığı \%14,47 pozitif yönde etkilemektedir. "Topaloğlu, (2009), Nazir ve Afza, (2009) Al-Shubiri (2011)" sonuçları çalışma sermayesi finansmanı için farklı sonuçları vermiştir. BİST KOBİ endeksine kayıtlı firmaların kaldıraç oranları aktif kârlılık oranını negatif yönde ve \%1 anlamlılık düzeyinde etkilemektedir." Çankaya (2020), Keskin ve Gökalp (2016), Şamiloğlu ve Demirgüneş (2008), Kedirli ve Çankaya (2016)" yaptıkları çalışmalar sonucunda ROA ve kaldıraç oranı arasında ortaya çıkan negatif yönlü ilişkiyi desteklemektedir. Kaldıraç oranındaki \%1'lik bir artış aktif kârlılığ \%30,41 azaltmaktadır. Satışların büyüklügünün aktif kârlılık oranına etkisiyse anlamlı değildir. 
Kurulan ikinci model ROE Beck-Katz tahmincisi ile kurulmuştur. Kurulan modelin sonuçları Tablo $11^{\prime}$ de gösterilmektedir.

Tablo 11: Model ROE Beck-Katz Dirençli Tahminci Sonuçları

\begin{tabular}{|c|c|c|}
\hline & Katsay1 & $\mathbf{P}>|\mathbf{Z}|$ \\
\hline CSYP & $0,1492^{*}$ & 0,001 \\
\hline CSFP & 0,2541 & 0,102 \\
\hline LEV & $-0,4880^{*}$ & 0,000 \\
\hline SB & $0,0661^{*}$ & 0,007 \\
\hline SABIT & $0,0601^{* *}$ & 0,031 \\
\hline \multicolumn{2}{|c|}{ Wald chi2(4) } & $47,63^{*}$ \\
\hline \multicolumn{2}{|c|}{ Prob > chi2 } & 0.0000 \\
\hline
\end{tabular}

Not: *(\%1) ve ** (\%5) anlamlılık düzeyini belirtmektedir.

Beck-Katz dirençli tahminci sonuçlarına göre Model ROE istatistiksel olarak anlamlıdır. Modeldeki bağımsız değişkenlerin özsermaye kârlılığı üzerindeki etkisi ise şu şekildedir. Çalışma sermaye yatırım politikası özsermaye kârlılığını \%1 anlamlılık düzeyinde ve pozitif yönde etkilemektedir. Çalışma sermayesi yatırım politikasındaki \%1'lik bir artış özsermaye kârlılığını \%14,92 pozitif yönde etkilemektedir. Çalışma sermayesi finansman politikasının özsermaye kârlılığı üzerindeki etkisi anlamsızdır. Kaldıraç oranının özsermaye etkisi istatistiksel olarak negatif yönlü ve anlamlıdır. Kaldıraç oranındaki bir birimlik bir artış özsermaye kârlılığını 0.4880 negatif etkilemektedir. ROE ile kaldıraç oranındaki negatif ve anlamlı yöndeki sonuç Yıldız ve Deniz (2020)'in çalışmasında da aynı sonucu vermektedir. Satışların büyüklüğü özsermaye kârlılığını \%1 anlamlılık düzeyinde ve pozitif yönde etkilemektedir. Satışlardaki \%1'lik bir artış özsermaye kârlılığını \%6 oranında etkilemektedir. Satışların büyüklüğünün özsermaye kârlılığına etkisi Kendirli ve Konak (2014)' deki çalışmasında benzer sonuçlar elde etmiştir. Bulgular sonucunda literatürdeki incelenen çalışmalarda da çalışma sermayesi ve firma kârlılığı arasında ilişkinin anlamlı olduğunu göstermekte ve çalışmanın sonuçlarını (Deloof, 2003; Dursun ve Ayrıçay 2012; Keskin ve Gökalp 2016; Korkmaz ve Yaman 2019) gibi çalışmalar destekler niteliktedir.

Tablo 12: Araştırmada Kullanılan Hipotezler ve Karar Sonuçları

\begin{tabular}{|c|c|c|c|}
\hline Hipotezler & Kullanılan Testler & P Anlamlılık Değeri & Karar \\
\hline $\boldsymbol{H}_{\mathbf{0 1}}$ & $\begin{array}{c}\text { Driscoll- Kraay Dirençli } \\
\text { Tahminci }\end{array}$ & $\begin{array}{c}\mathrm{P}<0,05 \\
(\mathrm{P}<0,008)\end{array}$ & RED \\
\hline $\boldsymbol{H}_{\mathbf{0 2}}$ & $\begin{array}{c}\text { Driscoll- Kraay Dirençli } \\
\text { Tahminci }\end{array}$ & $\begin{array}{c}\mathrm{P}<0,05 \\
(\mathrm{P}<0,030)\end{array}$ & RED \\
\hline $\boldsymbol{H}_{\mathbf{0 3}}$ & $\begin{array}{c}\text { Driscoll- Kraay Dirençli } \\
\text { Tahminci }\end{array}$ & $\begin{array}{c}\mathrm{P}<0,05 \\
(\mathrm{P}<0,001)\end{array}$ & RED \\
\hline $\boldsymbol{H}_{\mathbf{0 4}}$ & $\begin{array}{c}\mathrm{D} \text { (riscoll- Kraay Dirençli } \\
\text { Tahminci }\end{array}$ & $\begin{array}{c}\mathrm{P}>0,05 \\
(\mathrm{P}>0,588)\end{array}$ & KABUL \\
\hline $\boldsymbol{H}_{\mathbf{0 5}}$ & Beck-Katz Dirençli Tahminci & $\begin{array}{c}\mathrm{P}<0,05 \\
(\mathrm{P}<0,001)\end{array}$ & RED \\
\hline $\boldsymbol{H}_{\mathbf{0 6}}$ & Beck-Katz Dirençli Tahminci & $\begin{array}{c}\mathrm{P}>0,05 \\
(\mathrm{P}>0,102)\end{array}$ & KABUL \\
\hline $\boldsymbol{H}_{\mathbf{0 7}}$ & Beck-Katz Dirençli Tahminci & $\begin{array}{c}\mathrm{P}<0,05 \\
(\mathrm{P}<0,000)\end{array}$ & RED \\
\hline $\boldsymbol{H}_{\mathbf{0 8}}$ & Beck-Katz Dirençli Tahminci & $\begin{array}{c}\mathrm{P}<0,05 \\
(\mathrm{P}<0,007)\end{array}$ & RED \\
\hline
\end{tabular}

Çalışmanın hipotezleri değerlendirildiğinde " $H_{01}$ : Çalışma sermayesi yatııım politikasının aktif kârlılık üzerinde etkisi yoktur." sıfır hipotezi reddedilmiştir. Buna göre çalışma sermayesi yatırım politikasının aktif kârlılık üzerinde etkisi vardır. Bu etki Driscoll-Kraay direnç tahmincisine göre etkisinin pozitif yönde olduğuna ulaşılmıştır. " $H_{02}$ : Çalışma sermayesi finansman politikasının aktif kârlılık üzerinde etkisi yoktur." sıfır hipotezi reddedilmiştir. Bu sonuç yapılan analizler neticesinde çalışma sermayesi finansman politikalarının aktif kârlılık üzerinde pozitif etkisinin olduğu göstermektedir. " $H_{03}$ : Kaldıraç oranının aktif kârlılık üzerinde etkisi yoktur." sıfır hipotezi reddedilmiştir. Buna göre yapılan analizler sonucunda kaldıraç oranının aktif kârlılık üzerinde pozitif yönde etkisinin olduğu tespit edilmiştir. " $H_{04}$ : Satışların büyüklügünün aktif kârlılık üzerinde etkisi yoktur." sıfır hipotezi kabul edilmiştir. Driscoll- Kraay dirençli tahmincisi göre sonuç satışların büyüklügünün aktif kârlılık üzerinde etkisinin olmadığı sonucuna ulaşılmıştır. Beck-Katz dirençli tahmincisinin test sonuçlarına göre $H_{05}, H_{06}, H_{07}, H_{08}$ hipotezlerinin sonuçları şu sekildedir. " $H_{05}$ : Çalışma sermayesi yatırım politikasının özsermaye kârlılık 
üzerinde etkisi yoktur." sıfır hipotezi reddedilmiştir. Buna göre Çalışma sermayesi yatırım politikaları özsermaye kârlılığı üzerinde pozitif yönde bir etkisinin olduğu tespit edilmiştir. " $H_{06}$ : Çalışma sermayesi finansman politikasının özsermaye kârlılık üzerinde etkisi yoktur." sıfır hipotezi kabul edilmiştir. Bu sonuç ile birlikte çalışma sermayesi finansman politikalarının özsermaye kârlılı̆̆ı üzerinde bir etkinin olmadığı tespit edilmiştir. " $H_{07}$ : Kaldıraç oranının özsermaye kârlılık üzerinde etkisi yoktur." sıfır hipotezi reddedilmiştir. Bu sonuç ile kaldıraç oranının özsermaye kârlılığı üzerinde pozitif bir etkisinin olduğu sonucuna varmıştır. " $H_{08}$ : Satışların büyüklüğünün özsermaye kârlılık üzerinde etkisi yoktur." Sıfır hipotezi reddedilmiştir. Yapılan bu analizler neticesinde ise satışların büyüklüğünün özsermaye kârlılığına pozitif bir etkisinin var olduğu sonucuna ulaşılmıştır.

\section{Sonuç}

Bu çalışma, 2013 ve 2019 yıllarında sürekli faaliyet gösteren BİST'te kayıtlı 28 adet KOBİ sanayi işletmelerinin çalışma sermayesi yönetimi göstergelerinin firma kârlılığı üzerindeki etkisini sunmaktadır. Çalışmada firmaların mali tablolarından elde edilen veriler ile iki panel veri regresyon modeli kurulmuştur. Bağımlı değişken olan birinci model ROA ikinci model ise ROE'dır. Bağımsız değişkenler ise çalışma sermayesi yatırım politikaları (CSYP), çalışma sermayesi yatırım politikaları (CSFP), kaldıraç oranı (LEV) ve satışların büyüklüğü (SB)'dür. Bu regresyon modellerinde dirençli tahminciler kullanılarak elde edilen analizler sonucunda ROA ve ROE modellerinin istatistiksel olarak anlamlı olduğu sonucuna varılmıştır.

Çalışmada yapılan analizler neticesinde çalışma sermayesi yatırım politikası ve finansman politikasının aktif kârlılık oranına olan etkisi istatistiksel olarak anlamlı ve pozitif yönde iken; aktif kârlılığın kaldıraç oranına etkisi istatistiksel olarak anlamlı ve negatif yöndedir. Satışların büyüklügünün ise aktif kârlılık üzerinde bir etkisinin olmadığı sonucuna ulaşılmıştır. Özsermaye kârlığı modelinde çalışma sermayesi yatırım politikası ve satışların büyüklüğünün özsermaye kârlılığı üzerindeki etkisi pozitif yönlü ve istatistiksel olarak anlamlıdır. Ancak çalışma sermayesi finansman politikasının özsermaye kârlılı̆̆ı üzerinde düşük istatistiksel olarak anlamlı bir etkisinin bulunmadığı tespit edilmiştir. Kaldıraç oranının ise özsermaye kârlılığı üzerindeki etkisi negatif yönlü ve istatistiksel olarak anlamlıdır.

ROA ve ROE için kaldıraç oranının negatif yöndeki etkisinin kaldıraç oranının yüksek olduğu firmalarda aktif kârlılık ve özsermaye kârlılığını düşürdügünü göstermektedir. Yüksek kaldıraç oranı firmaların varlıkların finanse etmek için yabancı kaynak kullanımına işaret ettiği için artan (azalan) finansman maliyetleri kârlılık oranları üzerinde azaltıcı (artırıcı) bir etki yapmaktadır. Bu bağlamda, BISTT'teki KOBİ Sanayi firmalarının düşük kaldıraç oranları ile çalışmaları veya varlıklarına oranla daha fazla net kâra ulaşmak için gerekli politika değişikliklerine gitmelerinin gerekliliği göze çarpmaktadır. Diğer taraftan, daha fazla borçlanmaya yol açan nedenler arasında özsermaye yetersizliğinin olup olmadığı da önem taşımaktadır.

Artan rekabet koşulları ve belirsizlikle birlikte firmaların yaşamlarını başarılı bir şekilde sürdürebilmeleri için elde ettikleri yabancı kaynakları kullanma konusunda dönen varlıklara yapılan yatırımların önemi gittikçe artmaktadır. Firmalar çalışma sermayesi politikalarını belirlerken kârlılık ve risk arasında seçim yaparak stratejilerini belirlemektedirler. Çalışmada yapılan analizler sonucunda BIST KOBI Sanayi firmalarını agresif çalışma sermayesi yatırım politikasını benimsediği görülmektedir. Agresif çalışma sermayesi yatırım politikasını benimseyen firmalar dönen varlıklara daha az yatırım yaparak likiditenin düşük tutulmasını yeğlemektedirler. Böylelikle risk düzeyini arttırarak varlıklarını oluşturmaktadırlar. Bu gibi durumlarda firmalarda nakit ve stoklar için minimum güvenlik stoku bulundurulmalıdır. Bilindiği üzere, bu politikada daha yüksek kârlılık hedeflenmektedir. Regresyon sonuçlarına göre aktif ve özsermaye kârlılığı ile çalışma sermayesi yatırım politikaları arasında pozitif yönlü ilişki olduğu görülmektedir. Bu durumda agresif çalışma sermayesi firmanın kârlılığını da artırmaktadır.

Çalışma sermayesi finansman politikasının aktif kârlılığa olan etkisi pozitif ve anlamlıdır. Çalışmada değerlendirilen firmaların atılgan çalışma sermayesi finansal politikalarını benimseyerek duran varlıkları uzun vadeli yabancı kaynakla, sürekli ve değişen kısmını ise kısa vadeli yabancı kaynakla finanse ettiği izlenimi doğmaktadır. Atılgan çalışma sermayesi finansmanında, dönen varlıkların finansmanında uzun vadeli yabancı kaynak oranı diğer finansman politikalarından daha az olduğu için kredilerdeki yüksek faiz maliyeti azalmakta ve bu da kârlılığı artırmaktadır. BİST KOBİ Sanayi firmaları düşük faiz maliyetleri ile aktif kârlılı̆̆ını artırmış gözükmektedirler. Çalışmada kısa vadeli yabancı kaynaklarla tanımlanan çalışma sermayesinin finansmanının toplam aktif kârlılığı üzerindeki etkisinin pozitif yönlü olması, kaldıraç oranlarındaysa bunun tersi sonuca ulaşılması uzun vadeli yabancı kaynakların verimli kullanımıyla ilgili bir sorun olup olmadığını akla getirmektedir. Şüphesiz bu 
durum ayrıca araştırılabilir. Özsermaye kârlılığı ve çalışma sermayesi finansman politikaları arasında anlamsız ilişkinin çıkması sonucunda sonuç yorumlanamamıştır.

Satışların büyüklüğünün özsermaye kârlılığına etkisinde sonuç pozitif ve anlamlı çıkmıştır. Bu sonuç, firmaların satışlarını artmasının net kâr artışına yol açmasına paralel olarak özsermaye kârlılığını etkilemesinden kaynaklanmış olabilir.

Çalışma, BİST KOBİ firmalarının benimsediği çalışma sermayesi yönetiminin aktif ve özsermaye kârlılığını aktırmakta konusunda genel olarak etkili olduğu görülmektedir. Çalışma sermayesinin firma kârlılığını nasıl etkilediği konusunda kurulan modellerin sonuçlarının kendi sınırlılıkları içerisinde literatüre katkı sağlayacağı düşünülmektedir. Kobiler gerek gelişmiş ülkelerde gerekse gelişmekte olan ülke ekonomileri için büyük bir yer tutmaktadır. Bu sebeple Çalışma sermayesi yönetimi işletmelerin elde ettiği varlıklarını, kaynaklarını, en verimli şekilde kullanmaları hem kendi ekonomilerini hem de ülke ekonomisine çok önemlidir. Bu çalışma soncunda gelecekte yapılacak çalışmalarda gelişmiş ekonomilerde ve gelişmekte olan ekonomilerdeki KOBİler üzerinde çalışma sermayesinin firma kârlılığına olan etkisi incelenebilir.

\section{Hakem Değerlendirmesi / Peer-review:}

Dış bağımsız

Externally peer-reviewed

\section{Çıkar Çatışması / Conflict of interests:}

Yazar(lar) çıkar çatışması bildirmemiştir.

The author(s) has (have) no conflict of interest to declare.

\section{Finansal Destek/ Grant Support:}

Yazar(lar) bu çalışma için finansal destek almadığını beyan etmiştir.

The author(s) declared that this study has received no financial support.

\section{Yazar Katkıları / Author Contributions:}

Fikir/Kavram/Tasarım - Idea/Concept/Design: A.Ç. Veri Toplama ve/veya İşleme - Data Collection and/or Processing: Y.Y. Analiz ve/veya Yorum - Analysis and/or Interpretation: K.Ö. Kaynak Taraması - Literature Review: D.G., Makalenin Yazımı - Writing the Article: K.Ö., D.G. Eleştirel İnceleme - Critical Review: AÇ., Y.Y., Onay - Approval: A.Ç., Y.Y., K.Ö., D.G.

\section{Kaynakça / References}

Albayrak, A. S., \& Akbulut, R. (2012). Kârlılı̆̆1 Etkileyen Faktörler: İMKB Sanayi ve Hizmet Sektörlerinde İşlem Gören İşletmeler Üzerine Bir İnceleme, Uluslararası Yönetim İktisat ve İşletme Dergisi, 4(7), 55-82

Altaf, N. \& Ahmad, F. (2019). Working Capital Financing, Firm Performance and Financial Constraints. International Journal of Managerial Finance, 15(4), 464-477.

Aktaş, R. Doğanay, M.M. Gökmen Y. \& Somuncu, K. (2017). Finansal Yönetim, İstanbul: Beta Yayın Dağıtım.

Aksoy, A. \& Yalçıner, K. (2008). İşletme Sermayesi Yönetimi. (4. Baskı). Ankara: Gazi Kitabevi 
Akyüz, H. S. (2019). Çalışma Sermayesine İlişkin Finansal Oranların İşletme Karlılığına Etkisi: BİST İmalat Sektöründe Bir Uygulama. Çanakkale Onsekiz Mart Üniversitesi Uluslararası Sosyal Bilimler Dergisi, 4(2), 217-233.

Arslan, Ö. (2003). Küçük Ve Orta Ölçekli İşletmelerde Çalışma Sermayesi Ve Bazı Finansal Yönetim Uygulamaları. Cumhuriyet Ünivesitesi İktisadi ve İdari Bilimler Dergisi, 4(1), 121-135.

Atmaca, M. (2016). Finansal Oranlar Aracılığıyla Çalışma Sermayesi Bileşenlerinin Karlılığa Etkisi: Borsa İstanbul'da İşlem Gören Kimya, Plastik ve Kauçuk Şirketlerinde Bir Araştırma. Yönetim Bilimleri Dergisi, 14(28), 633-649.

Aygün, M. (2012). Firma Performansı Üzerinde Çalışma Sermayesinin Etkisi: Türk İmalat Sektörü Üzerine Bir Uygulama, Ege Akademik Bakış, 12(2), 215-223.

Aytürk, Y. \& Yanik, S. (2015). Çalışma Sermayesi Yönetimi Türkiye'deki KOBİ'lerde Karlılığı Nasıl Etkiler? Muhasebe ve Finansman Dergisi, (68), 157-168.

Breush, T.S. \& Pagan, A.R. (1979), A Simple Test For Heteroscedasticity And Random Coefficient Variation. Econometrica: Journal of the Econometric Society 47(5), 1287-1294.

Brown, M. B. \& Forsythe, A.B. (1974). Robust Tests Fort He Equality Of Variances. Journal Of The American Statistical Association, 69(346), 364-367.

Coşkun, E. \& Kök D. (2011). Çalışma Sermayesi Politikalarının Karlılık Üzerine Etkisi: Dinamik Panel Uygulaması. Ege Akademik Bakış, 11(Özel Sayı), 75-85.

Çankaya, M. (2002). Sağlık Sektörü İşletmelerinde İşletme Sermayesi Yönetiminin Karlılık Üzerindeki Etkisi: Borsa İstanbul (BİST) Örneği. Aksaray Üniversitesi İktisadi ve İdari Bilimler Fakültesi Dergisi, 12(4), 1-14.

Çerçel, Ö. N., \& Sökmen, A. G. (2019). Çalışma Sermayesi Yönetiminin Firma Kârlılığı Üzerindeki Etkisi: BISTT'te İşlem Gören Metal Eşya, Makine ve Gereç Yapım Sektörü Üzerinde Bir Araştırma. Çă̆g Üniversitesi Sosyal Bilimler Dergisi, 16(2), 35-42.

Çınar, Ö. \& Kaymaz, M. T., (2020). Çalışma Sermayesi ile Firma Kârlılı̆̆ı İlişkisinin Panel Veri ile Analizi: BİST'te Kayıtlı Üretim Firmaları Üzerine Bir Uygulama (2009-2018). I Ĭgır Üniversitesi Sosyal Bilimler Dergisi (23).

Deloof, M. (2003). Does Working Capital Management Affect Profitability Of Belgian Firms? Journal Of Business, Finance and Accounting, 30(3), 573-587.

Dinçergök, B. (2019). İşletme Sermayesi Yönetimi ve Karlılık ilişkisi: Doğrusal Olmayan İlişkinin BİST Kimya, Petrol, Kauçuk ve Plastik Ürünler Sektöründe Sınanması. Muhasebe ve Finansman Dergisi, (82), ss. 161-176.

Doğan, M. \& Elitaş, B. L.(2014). Çalı̧̧ma Sermayesi Gereksiniminin Belirleyicileri: Borsa İstanbul Gida Sektörü Üzerine Bir İnceleme. World of Accounting Science, 16(2).

Driscoll J.C. \& Kraay, A.C. (1998). Consistent Covariance Matrix Estimation with Spatially Dependent Panel Data. Review of Economics and Statistics, 80, 549-560.

Dursun, A. \& Ayrıçay, Y. (2012). Çalışma Sermayesi-Karlılık İlişkisinin İMKB Örneğinde 19962005dönemi Analizi. Atatürk Üniversitesi İktisadi ve İdari Bilimler Dergisi, 26(3-4), 199-214.

Erbul, M. \& Özdemir, F. S. (2020). Çalışma Sermayesi Yönetiminin Firma Performansı Üzerindeki Etkisi: Borsa İstanbul Yıldız Endeksinde Bir Uygulama. Ömer Halisdemir Universitesi Iktisadi ve Idari Bilimler Fakültesi Dergisi, 14(1), 335-348.

Ercan, M.K. \& Ban, Ü. (2008). Finansal Yönetim. (4. Bask1), Ankara: Gazi Kitapevi.

Erdaş, M.L. (2015). Firma Karlılı̆̆ Üzerinde Çalışma Sermayesi Yönetiminin ve Makroekonomik Faktörlerin Etkisi: Borsa İstanbul Endeksi Turizm Sektöründe Faaliyet Gösteren Firmalar Üzerine Bir Uygulama. Uluslararası Sosyal Araştırmalar Dergisi, 8(41), 1220-1229.

Eskin, İ. \& Güvemli, B. (2020). Çalışma Sermayesi Yönetiminin Kârlılığa Etkisi: Borsa İstanbul 50 Endeksi Örneği. Muhasebe ve Finansman Dergisi, 85, 65-76.

García-Teruel, P. J. \& Martínez-Solano, P. (2007). Effects of Working Capital Management on SME Profitability. International Journal of Managerial Finance, 3(2),164-177. 
Güdelci, E. N. (2016). İşletme Düzeyinde Çalışma Sermayesi ve Karlılık İlişkisi-BíST'de Faaliyet Gösteren Gübre İşletmeleri Üzerine Bir Çalışma. Batman Üniversitesi Yaşam Bilimleri Dergisi, 6(2/1), 183-192.

Hausman, J.A. (1978). Specification Tests İn Econometrics. Econometrica, 46(6), 1251-1271.

Irmak, F. (2016). Küresel finansal kriz dönemlerinde çalışma sermayesi yönetiminin firma performansına etkisi: BİST imalat sanayi endeksinde bir çalışma. Yüksek Lisans Tezi, Hitit Üniversitesi Sosyal Bilimler Enstitüsü, Mardin.

Karagözoğlu, G. \& Aktaş, R. (2018). İmalat Sektöründeki İşletmelerde Çalışma Sermayesi Belirleyicileri BİST Örneği. Celal Bayar Üniversitesi İktisadi ve İdari Bilimler Fakültesi Dergisi, 25(3), 713-733.

Kendirli, S. \& Çankaya, M. (2016). BİST Turizm Endeksindeki Şirketlerde İşletme Sermayesi Yönetiminin Karlılık Üzerindeki Etkisini Ölçmeye Yönelik Bir Araştırma. International Review Of Economics And Management, 4(2), 46-68.

Kendirli, S. \& Konak, F. (2014). İşletme (Çalışma) Sermayesi Yönetiminin Firma Performansı Üzerindeki Etkisi: BİsT Gıda, İçecek Endeksi Uygulaması. Akademik Bakış Dergisi, 41(3), 1-17

Keskin, R. \& Gökalp, F. (2016). Çalışma Sermaye Yönetiminin Firma Karlılı̆̆̆ Üzerine Etkisi: Panel Veri Analizi. Doğuş Üniversitesi Dergisi, 17(1), 15-25.

Kılıç, M. (2019). Bankaların Finansal Yapısının Karlılık Üzerindeki Etkisi: Özel Sermayeli Mevduat Bankaları Üzerine Bir İnceleme. Uluslararası İktisadi ve İdari İncelemeler Dergisi, (24), 45-58.

Kisakürek, M., Babacan, A., \& Tuncay, M. (2018). Türkiye'de Sektörel Düzeyde Çalışma Sermayesi Unsurları ile Finansal Performans Arasındaki Etkileşim. Kahramanmaraş Sütçü İmam Üniversitesi Sosyal Bilimler Dergisi, 15(2), 315-331.

Konak, F. \& Güner, E. N. (2016). İşletme sermayesi yönetiminin firma performansı üzerindeki etkisi: BIST KOBI endüstriyel endeksinden deneysel bir kantt. Uluslararası Ticaret, Ekonomi ve Finans Dergisi, $7(2), 38-43$.

Korkmaz, T. \& Yaman, S. (2019). Çalışma Sermayesi Yönetiminin Firma Karlılı̆̆ına Etkisi: BísT Turizm Firmaları Üzerine Bir Uygulama. Journal of Tourism Theory And Research, 5(2), 301-316.

Le, B. (2019). Working Capital Management And Firm's Valuation, Profitability And Risk. International Journal of Managerial Finance,15(2), 191-204.

Çakır, H. M. \& Küçükkaplan, İ. (2012). İşletme Sermayesi Unsurlarının Firma Değeri ve Karlılığı Üzerindeki Etkisinin İMKB'de İşlem Gören Üretim Firmalarında 2000-2009 Dönemi İçin Analizi. Muhasebe ve Finansman Dergisi, (53), 69-86.

Nazir, M.S. \& Afza, T. (2009). Impact of Aggressive Working Capital Management Policy on Firms'Profitability, The IUP Journal of Applied Finance, 15(8), 19-30.

Okka, O. (2018). Finansal Yönetim Teori ve Çözümlü Problemleri-A2 Finans Serisi. (7. Baskı) Ankara: Nobel Yayıncilik.

Öndeş, T. \& Pagheh, E. (2018). Firmaların İşletme Sermayesi Stratejileri ile Risk, Getiri ve Karlılık Yetenekleri Arasındaki İlişkinin İncelenmesi: BİST Üzerine Ampirik Bir Çalışma. Studies, 4(21), 801813.

Öz Y. \& Güngör B. (2007). Çalışma Sermayesi Yönetiminin Şirket Kârlılığı Üzerine Etkisi: İmalat Sektörüne Yönelik Panel Veri Analizi, Atatürk Üniversitesi Sosyal Bilimler Enstitüsü Dergisi, 10(2), 319332.

Pais, M. A. \& Gama, P. M. (2015). Working capital management and SMEs profitability: Portuguese evidence. International Journal of Managerial Finance, 11(3), 341-358.

Prasad, P., Sivasankaran, N. \& Shukla, A. (2019). Impact Of Deviation From Target Working Capital On Firm Profitability: Evidence From India. International Journal of Productivity and Performance Management, 68(8), 1510-1527.

Poyraz, E. (2012). İşletme Sermayesi Finanslama Stratejilerinin Karlılık Oranları Üzerindeki Etkisi (Akbank Ta Ş. Uygulaması). Dokuz Eylül Üniversitesi İktisadi İdari Bilimler Fakültesi Dergisi, 27(1), 4756.

Sevil, G. \& Başar, M. (Ed), (2014). Finansal Yönetim. Eskişehir: Anadolu Üniversitesi. 
Sharif, M. A. \& Islam, M. R. (2018). Working Capital Management A Measurement Tool For Profitability: A Study on Pharmaceutical İndustry İn Bangladesh. Journal of Finance And Accounting, 6(1), 1-10.

Şahin O. (2011). İMKB'ye Kayıtlı İmalat Şirketlerinde Çalışma Sermayesi Politikaları Ve Firma Performansı İlişkileri. Eskişehir Osmangazi Üniversitesi İIBF Dergisi, 6(2), 123-141.

Şamiloğlu, F. \& Demirgüneş, K. (2008). The Effect of Working Capital Management on Firm Profitability: Evidence From Turkey. The International Journal of Applied Economics and Finance, 2(1), 44-50.

Tatoğlu, F. Y. (2013). Panel Veri Ekonometrisi: Stata Uygulamalı. İstanbul: Beta Bastm.

Tatoğlu, F. Y. (2020). Panel Veri Ekonometrisi: Stata Uygulamalı. İstanbul: Beta Basım.

Topaloğlu, T. N. (2019). Çalışma Sermayesi Yatırım ve Finansman Politikalarının Firma Karlılığına Etkisi: BIST 30 Firmaları Üzerine Panel Veri Analizi. Uluslararası Ekonomi Siyaset İnsan ve Toplum Bilimleri Dergisi, 2(2), 88-106.

Yıldız, B. \& Deniz, T. (2020). BİST Yıldız Endeksinde İşlem Gören Firmaların Kârlılıklarına Etki Eden Çalışma Sermayesi Faktörleri" Journal of Research İ Economics, Politics \& Finance, 2020, 5(1): 91-110.

Yücel, T., \& Kurt, G. (2002). "Nakit Dönüş Süresi Nakit Yönetimi ve Karlılık: IMMKB Şirketleri Üzerinde Ampirik Bir Çalışma". IMMKB Dergisi, 1-15.

Zengin, B. \& Tanrıöven, C. (2016). Kriz Dönemlerinde Çalışma Sermayesi Yönetimi Etkinliğinin Analizi, BIST İmalat Sanayi İşletmelerinde Uygulama. Dumlupınar Üniversitesi Sosyal Bilimler Dergisi, (50), $162-179$. 